\title{
Maya Hadeh, Mythologie de la Chauve-Souris. Le Vampire et ses avatars chez Baudelaire et Barbey d'Aurevilly
}

\section{Maria Emanuela Raffi}

\section{(2) OpenEdition \\ Journals}

\section{Edizione digitale}

URL: http://journals.openedition.org/studifrancesi/6991

DOI: 10.4000/studifrancesi.6991

ISSN: 2421-5856

\section{Editore}

Rosenberg \& Sellier

\section{Edizione cartacea}

Data di pubblicazione: 1 septembre 2010

Paginazione: 396-397

ISSN: 0039-2944

\section{Notizia bibliografica digitale}

Maria Emanuela Raffi, «Maya Hadeh, Mythologie de la Chauve-Souris. Le Vampire et ses avatars chez Baudelaire et Barbey d'Aurevilly», Studi Francesi [Online], 161 (LIV | II) | 2010, online dal 30 novembre 2015, consultato il 09 janvier 2021. URL: http://journals.openedition.org/studifrancesi/6991 ; DOI: https://doi.org/10.4000/studifrancesi.6991

Questo documento è stato generato automaticamente il 9 janvier 2021.

\section{cc) (†) $\odot$}

Studi Francesi è distribuita con Licenza Creative Commons Attribuzione - Non commerciale - Non opere derivate 4.0 Internazionale. 


\title{
Maya Hadeh, Mythologie de la Chauve- Souris. Le Vampire et ses avatars chez Baudelaire et Barbey d'Aurevilly
}

\author{
Maria Emanuela Raffi
}

\section{NOTIZIA}

MAYA HADEH, Mythologie de la Chauve-Souris. Le Vampire et ses avatars chez Baudelaire et Barbey d'Aurevilly, «French Forum», vol. 33, nos. 1-2, Winter/Spring 2008, pp. 37-52.

La figura del vampiro, rappresentata nella letteratura francese del XIX secolo soprattutto come figura femminile e spesso assimilata all'immagine del pipistrello, è l'oggetto dello studio di Maya Hadeh, che prende in esame due opere emblematiche: Une vieille maîtresse di Barbey d'Aurevilly e Les Fleurs du Mal di Baudelaire. Sospeso fra maschile e femminile e dotato di un fascino animalesco e angosciante, il vampiro di Barbey appare a Maya Hadeh come il corrispondente narrativo della donna-vampiro baudelairiana, anch'essa creatura notturna, inquietante e seduttiva, che rinvia alla biblica Lilith. Tutta una serie di poesie - «Le revenant», «Le Vampire», «Le Possédé» mostrano, in parallelo con il racconto Une vieille maîtresse, i caratteri specifici di questo tipo di vampiro: sado-masochismo e quindi ambivalenza del rapporto carnefice/ vittima, perversione legata all'infrazione del tabù atavico legato al bere sangue umano (particolarmente sottolineato in «L'Ennemi» di Baudelaire e nel filtro di sangue offerto dalla Vellini a Ryno nel racconto di Barbey), versamento di lacrime. Fra questi, tuttavia, il tema del sangue è certamente il più presente in entrambi gli autori considerati: «Saigne, saigne mon cœur...» di Barbey e soprattutto «La fontaine de Sang» di Baudelaire mostrano una fissazione quasi ossessiva per "l'écoulement de son propre sang". 